\section{Kovalenko 0., Kormosh K., Velichko T., Vasyliv 0., Yemonakova $\mathbf{0}$.}

\title{
INFLUENCE OF CONDITIONS OF WATER PRODUCTION FROM AIR ON THE MICROBIOCENOSIS OF CONDENSATE
}

Представлені результати теоретичних і експериментальних досліджень впливу різних факторів на мікробіоценоз води із повітря. Встановлені закономірності між забрудненістю атмосферного повітря різними домішками, а також особливостями експлуатацї настінних кондиціонерів спліт-систем та низкою показників мікробіологічного забруднення води. Показано, що вода, отримана із повітря за допомогою побутових кондиціонерів, характеризується значним мікробіологічним забрудненням і без спечіального очищення використовувати ї̈ для питних потреб небезпечно.

Ключові слова: атмосферне повітря, побутовий кондиціонер, якість води, мікробіоценоз води із повітря.

\section{Introduction}

Water production from the air is one of the ways of alternative supply of drinking or technical water to regions with a deficit of fresh water. In particular, it is possible to use such water in recreational areas of the south and east of Ukraine that do not have centralized water supply, and the quality of water from natural underground or surface sources is of low quality and requires a complex and expensive water treatment technology [1]. Also, it is possible to receive and use water from the air in the ATO zone [2].

To produce water from atmospheric air, various devices are used today, among which are also air conditioners. In modern sanatorium-resort complexes a significant number of domestic air conditioners are located. In the summer they are used to cool indoor air. The water, which is formed in them, is a secondary product, which, as a rule, is not used anywhere. Although the amount of it is enough to use after additional treatment and conditioning for certain needs of recreation center or sanatorium [1]. Therefore, the development of water treatment technology is topical, and the primary task of this work is studying the influence of the conditions for water production from air on its quality. The established regularities allow to determine the conditions under which water from air will have the best organoleptic, chemical and microbiological indices, and the technology of its further processing will require less resource costs.

\section{The object of research and its technological audit}

The object of research is the microbiocenosis of water, produced from atmospheric air with the help of domestic conditioners of split systems. The necessity of studying the microbiocenosis of water is primarily due to the fact that the specific features of its species and quantity make it possible to determine the epidemiological safety of such water and the possibility of its use in drinking or techni- cal water supply. After all, the use of water, the quality of which does not meet the current hygiene standards, can lead to infectious diseases and parasitic infestations in humans.

One of the most problematic places of study of this object is that the microbiocenosis of the aquatic environment is characterized by a considerable variety of microorganisms. Therefore, within the framework of this work, only microbiological indices regulated by DSanPiN «Hygienic requirements for drinking water intended for human consumption» are determined [3]. In particular, the indicators of epidemic safety (total microbial number, bacteria of E. coli, Pseudomonas aeruginosa, Staphylococcus aureus), as well as a group of micromycetes, are determined. Information on these indicators is sufficient to justify the choice of effective technological regimes for the process of water disinfection and disinfection of containers and equipment that contact with water.

\section{The aim and objectives of research}

The aim of research is investigation of the influence of the conditions for water production from the air on its quality indicators, in particular microbiological ones.

To achieve this aim, it is necessary to solve the following tasks:

1. Determine the atmospheric conditions and the content of pollutants in the air in experimental air-conditioners.

2. Determine the effect of placing sampling points of air samples relative to sea level and remoteness from industrial enterprises, transport highways and the coastal strip to the level of air pollution.

3. Define the indicators of epidemical safety and other microbiological indicators of water produced from the air with the help of various wall conditioners of split systems operating in the «cooling» mode of indoor air.

4. Establish a relationship between air pollution, climatic conditions, design features and operating conditions of domestic air conditioners in split systems and microbiological quality indicators produced from air. 
5. Determine the conditions under which the condensate of atmospheric moisture from wall conditioners of split systems is expedient for use for drinking or technical needs.

\section{Research of existing solutions of the system}

To produce water from the air today use autonomous type wind generators, which produce electrical energy and water [4]. Also known about big-boards with a combined surface of hydrophilic and hydrophobic materials [5], «aquiferous trees» [6] or mesh panels with water-absorbing materials. In the offices for water production from the air, air dryers are used [7]. For regions with water and energy deficiency, it is proposed to use absorbing water ammonia refrigeration machines, solar radiation is used as an energy source [8]. Also, a domestic air conditioner can be used to produce water from the air [9-11].

A review of the literature on the problem of water production from air using air conditioners shows that very little research has been devoted to the quality of such water and the influence of various factors on it. Therefore, probably, in the discussions of this topic are presented completely opposite opinions. Some authors believe that the condensate from the conditioner can't be used for a person, and for technical needs it is suitable [12]. Others, on the contrary, say that such water is fairly clean [2]. There are also more thorough reflections on this issue. The authors note that the quality of the condensate from the air conditioner depends on the dust content of the air, the materials of the air conditioner, the correct installation of drainage pipes and the like. In this connection, the pollutants obtained from the air can contain various pollutants and their concentration will also be different. And after special treatment, water condensate from the conditioner can be used both in drinking (people, animals) and in technical water supply (irrigation of the land, watering of greenery, sanitation of premises and territories, work of fountains and cooling towers, etc.) [13-15].

Quite a different situation with the development of technical issues of water production from the air. In the literature [2, 4-11], various designs, calculation techniques and approaches to designing equipment or devices with which to condense atmospheric moisture are presented. It should be noted that the authors of the work have previously carried out experimental studies of the quality of water produced from the air with the employer of a domestic air conditioner [1]. But the study of the change in water quality, depending on the conditions in which it is obtained, was not conducted. And as noted above, such studies are important.

\section{Methods of research}

In the experiment, samples of water from the air are obtained during the operation of three household wall air conditioners. It should be noted that all air conditioners have been in operation for a long time at the time of the experiment. They cooled the air in the recreation centers on the territory of recreational areas and restaurant facilities along the Black Sea coast in Odessa and the Odessa region, Ukraine.
Places for obtaining samples of water from the air were selected so that they are used to produce air conditioners of the same manufacturer with the same technical characteristics (type of air conditioner, cooling capacity, voltage, type of refrigerant, circulating air flow). The air conditioners differed in design characteristics, namely the type of compressors and the system of filters for air purification (Table 1) [16, 17].

Table 1

Technical and design characteristics of experimental air conditioners

\begin{tabular}{|c|c|c|}
\hline \multirow{2}{*}{ Main characteristics } & \multicolumn{2}{|c|}{$\begin{array}{l}\text { Model of air conditioner and its number } \\
\text { in the experiment }\end{array}$} \\
\hline & $\begin{array}{l}\text { Sensei FTB-25GR } \\
\text { (conditioner No.1) }\end{array}$ & $\begin{array}{c}\text { Sensei FTI-25MR } \\
\text { (conditioners No.2 and No.3) }\end{array}$ \\
\hline Type of air conditioner & split system & split system \\
\hline Compressor type & not inverter & inverter \\
\hline Cooling capacity, kW & 2.5 & 2.5 \\
\hline $\begin{array}{l}\text { Power consumption in } \\
\text { cooling mode, W }\end{array}$ & 0.82 & 0.65 \\
\hline $\begin{array}{l}\text { Nominal voltage in } \\
\text { cooling mode, V }\end{array}$ & 220 & 220 \\
\hline $\begin{array}{l}\text { Minimum air tempera- } \\
\text { ture in cooling mode, }{ }^{\circ} \mathrm{C}\end{array}$ & +18 & +18 \\
\hline Refrigerant & Freon R410A & Freon R410A \\
\hline Drying mode, l/h & 1 & 1 \\
\hline $\begin{array}{l}\text { Circulating air consum- } \\
\text { ption, } \mathrm{m}^{3} / \mathrm{h}\end{array}$ & 500 & 500 \\
\hline Evaporator material & \multicolumn{2}{|c|}{$\begin{array}{l}\text { Copper tubes with hydrophilic aluminum finning } \\
\text { exhibiting anticorrosive properties }\end{array}$} \\
\hline Air conditioner filters & mechanical+plasma & mechanical+antioxidant \\
\hline Other functions & ionizer, autorestart & ionizer, autorestart \\
\hline
\end{tabular}

The height of placement of air conditioners above sea level and remoteness of air conditioners from pollution sources (industrial enterprises, transport mains) and the coastal strip is also different (Table 2). The distance between air conditioners and sources of air pollution is roughly determined by a geographical map in a straight line drawn from one point to another.

Tahle 2

Location of air conditioners in the experiment

\begin{tabular}{|l|c|c|c|}
\hline \multirow{2}{*}{\multicolumn{1}{|c|}{ Characteristic }} & \multicolumn{3}{|c|}{ Conditioner } \\
\cline { 2 - 4 } No. 1 & No. 2 & No. 3 \\
\hline $\begin{array}{l}\text { Geographical location of the air } \\
\text { conditioner }\end{array}$ & $\begin{array}{c}\text { Odessa region, } \\
\text { Kominternovsky dis- } \\
\text { trict, Chernomorske, } \\
\text { recreation center } \\
\text { «Chabanka» }\end{array}$ & $\begin{array}{c}\text { Odessa, 13 } \\
\text { station of } \\
\text { Bolshoy Fon- } \\
\text { tan, «hiviera» } \\
\text { beach area }\end{array}$ & $\begin{array}{c}\text { Odessa, } \\
\text { Langeron } \\
\text { beach }\end{array}$ \\
\hline $\begin{array}{l}\text { Height of the conditioner above sea } \\
\text { level, m }\end{array}$ & 2.8 & 3.0 & 2.5 \\
\hline $\begin{array}{l}\text { Remoteness from: } \\
\text { - coastal strip, m }\end{array}$ & 250.0 & 100.0 & 150 \\
\hline - from the center of Odessa, km & 32 & 15 & 3 \\
\hline - Odessa railway station, km & 23 & 9.1 & 2.5 \\
\hline - Odessa sea port, km & 27 & 12 & 2.6 \\
\hline - J5C Odessa Port Plant, km & 24 & 58 & 47 \\
\hline - Sea trading port «Yuzhny», km & 27 & 61 & 50 \\
\hline - J5C «Ddessa Refinery», km & 18 & 20 & 9.3 \\
\hline - Odessa International Airport, km & 27 & 11 & 11 \\
\hline
\end{tabular}


Samples of water from 3 air conditioners for this study were obtained during the day $(30 / 05 / 2016)$. To determine the quality indicators, water samples taken around midday and midnight were used. In the obtained water samples, the epidemiological safety indicators were deter- mined (Table 3 ). The obtained values of water quality indicators from air were compared with the requirements of [3]. Also, the values of similar quality indicators of water samples obtained from air under different conditions were compared.

Methods and basic equipment used to determine indicators of epidemic safety of water

\begin{tabular}{|c|c|c|c|}
\hline No. & $\begin{array}{l}\text { Water quality } \\
\text { index, unit of } \\
\text { measure }\end{array}$ & Method of research & Laboratory equipment, devices, materials \\
\hline 1 & $\begin{array}{l}\text { Total micro- } \\
\text { bial number, } \\
\text { CFU in } \mathrm{cm}^{3} \text { : } \\
\text { - at } 22^{\circ} \mathrm{C} \text {; } \\
\text { - at } 37^{\circ} \mathrm{C}\end{array}$ & $\begin{array}{l}\text { The method of deep sowing a sample of water in nutrient agar } \\
\text { and counting all colonies of microorganisms that can be seen at } \\
\text { ( } 2-5) \text { fold increase, grown at a temperature }(36 \pm 1) \text { ' }[\text { during } \\
(24 \pm 2) \text { hours or at }(22 \pm 1) \text { ' }[\text { for } 48 \text { hours in the depth and } \\
\text { on the surface of the nutrient agar }[18,19]\end{array}$ & \multirow{7}{*}{ 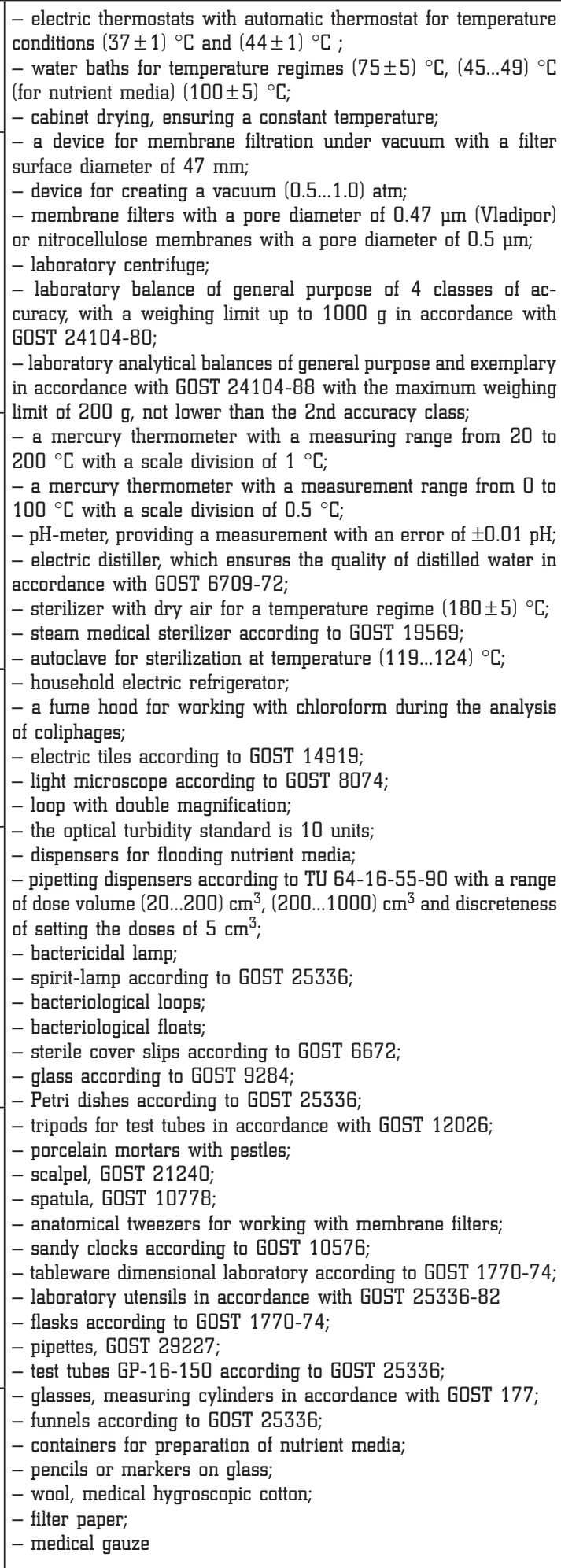 } \\
\hline 2 & & $\begin{array}{l}\text { The method consists in filtration of a certain volume of water } \\
\text { through membrane filters, cultivation of crops on a differential di- } \\
\text { agnostic nutrient medium with lactose and subsequent identification } \\
\text { of colonies for cultural and biochemical properties. It is taken into } \\
\text { account that the total coliform bacteria are gram negative, have no } \\
\text { spores, oxidase-negative rods that ferment glucose and lactose to } \\
\text { acid, aldehyde and gas at ( } 37 \pm 1)^{\circ} \mathrm{C} \text { for ( } 24 . . .48 \text { ) hours. Among } \\
\text { the common coliform bacteria are thermotolerant coliform bacteria } \\
\text { that possess all of their characteristics and, in addition, are able } \\
\text { to ferment lactose to acid, aldehyde and gas at a temperature of } \\
(44 \pm 0.5)^{\circ} \mathrm{C} \text { for } 24 \text { hours }[18,20]\end{array}$ & \\
\hline 3 & $\begin{array}{l}\text { Escherichia } \\
\text { coli, CFU per } \\
100 \mathrm{~cm}^{3}\end{array}$ & $\begin{array}{l}\text { The method of determination consists in concentrating the bacteria } \\
\text { from a certain volume of water using a membrane filter, incubating } \\
\text { them at ( } 37 \pm 0.5){ }^{\circ} \mathrm{C} \text { on Kessler's and Endo's medium, differen- } \\
\text { tiating the grown colonies and counting the number of bacteria } \\
\text { of the Escherichia coli group per } 1 \mathrm{dm} \text { of water. In the case of } \\
\text { detection of gas in the culture medium or dark red colonies with } \\
\text { metallic luster, then } 2-3 \text { such colonies from each sector are sown } \\
\text { in parallel to tubes with a lactose medium and Hottinger broth to } \\
\text { confirm the presence of } E \text {. coli. The lactose medium is preheated } \\
\text { on a water bath to a temperature of }(43 . .44)^{\circ}[\text { [18] }\end{array}$ & \\
\hline 4 & $\begin{array}{l}\text { Enterococci, } \\
\text { CFU рег } \\
100 \mathrm{~cm}^{3}\end{array}$ & $\begin{array}{l}\text { The method for the determination of enterococci ( } E \text {. faecalis, } \\
\text { E. faecium, E. avium, E. gallinarum) involves inoculation of a certain } \\
\text { amount of the product when it is diluted in a liquid elective medium } \\
\text { or on the surface of a dense elective medium, aerobic cultivation } \\
\text { of crops at ( } 37 \pm 1 \text { ) ' } C \text { during ( } 24 . .48 \text { ) hours, differentiation of } \\
\text { the grown up colonies and its counting of microorganisms [21] }\end{array}$ & \\
\hline 5 & $\begin{array}{l}\text { Pseudamonas } \\
\text { aeruginosa, } \\
\text { CFU per } \\
100 \mathrm{~cm}^{3}\end{array}$ & $\begin{array}{l}\text { The determination is carried out by a microbiological method, in } \\
\text { which the pigmentation ability is an important diagnostic feature. } \\
\text { The method involves inoculation of the test material on a solid } \\
\text { nutrient medium, incubating the crop under aerobic conditions at } \\
\text { ( } 37 \pm 1)^{\circ} \mathrm{C} \text { for (16...18) hours. The resulting bacterial mass in the } \\
\text { amount of one bacteriological loop is placed in } 300 \mathrm{~cm}^{3} \text { of physi- } \\
\text { ological solution and heated at ( } 98 . . .99){ }^{\circ}[\text { for }(20 . .30 \text { ) minutes, } \\
\text { centrifuged at } 12000 \text { rpm for } 30 \text { seconds. To the supernatant, a dye } \\
\text { for electrophoretic detection in an amount of } 0.5 \mathrm{~cm}^{3} \text { and } 20 \mathrm{~cm}^{3} \\
\text { is added. } 1.2 \% \text { of agarose gel on a TAE buffer with } 10 \mathrm{~cm}^{3} \text { of } \\
1 \% \text { ethidium bromide is needed in a } 4 \times 1 \mathrm{~mm} \text { well }[22,23]\end{array}$ & \\
\hline 6 & $\begin{array}{l}\text { Staphylacac- } \\
\text { cus aureus }\end{array}$ & $\begin{array}{l}\text { The method involves filtering a sample in a volume of } 50 \mathrm{ml} \\
\text { through } 2 \text { or } 3 \text { filters to obtain isolated colonies, placing the filters } \\
\text { on milk-yolk-salt agar and incubating at } 37 \text { ' } \mathrm{C} \text { for } 24 \text { hours. } \\
\text { Next, the convex shiny colonies of white, pale yellow, golden in } \\
\text { color are surrounded, surrounded by an iridescent with a pearly } \\
\text { shine zone. If it is necessary to confirm the belonging of bacteria } \\
\text { to Staphylococcus aureus, suspicious colonies are transferred to } \\
\text { milk-yolk agar with plaques, microscopy, the plasma-coagulase } \\
\text { activity is determined. In the presence of small gram-positive } \\
\text { cocci, located in the form of grapes, and coagulated plasma give } \\
\text { a positive response [24] }\end{array}$ & \\
\hline 7 & $\begin{array}{l}\text { Micramy- } \\
\text { cetes: } \\
\text { Aspergillus } \\
\text { Penicillum } \\
\text { Cladosporium }\end{array}$ & $\begin{array}{l}\text { The method involves inoculation of water samples on a specific } \\
\text { agar medium with subsequent incubation, counting and identifica- } \\
\text { tion of the grown colonies. The procedure involves preparation of } \\
\text { water samples, filtration through membrane filters, which are then } \\
\text { applied to the surface of an agarized Saburo nutrient medium with } \\
\text { dichlorane at a concentration of } 2 \mu \mathrm{g} / \mathrm{cm}^{3} \text { (prevents the creeping of } \\
\text { fungi, which makes it difficult to count individual colonies) }[25,26]\end{array}$ & \\
\hline
\end{tabular}


To determine the effect of air pollution in the location of air conditioners on the quality of water from the air, studies were made of the content of various impurities in the air. The studies were carried out in parallel with the sampling of water on the day and time indicated above. For this purpose, a post-environmental mobile modernized ПЕП-1-1M (Russia) was used, designed for operational observations of surface air pollution, including measurements of mass concentrations and control of the content of pollutants such as $\mathrm{CO}, \mathrm{NO}_{2}, \mathrm{NO}, \mathrm{SO}_{2}, \mathrm{H}_{2} \mathrm{~S}$, dust, hydrocarbons (saturated, unsaturated and aromatic), ammonia, ozone. ПЕП-1-1M is a device with alphanumeric and digital indication of the measured parameters on a liquid crystal display, with the possibility of storing up to 250 measurement results [27]. The measurements were carried out using gas analyzers, a dust analyzer and a chromatograph, which are part of the ПЕП-1-1M. Table 4 shows the methods and equipment used to determine the content of pollutants in the air in the location of air conditioners.
The mobile environmental post ПЕП-1-1M was also used to determine atmospheric conditions in the locations of air conditioners. In particular, using the automatic meteorological complex, which is a part of ПЕП-1-1M, measured the temperature and relative humidity of air, atmospheric pressure and wind speed. The condensate temperature and its quantity were also determined.

The environmental mobile post, as well as assistance in determining air pollution and atmospheric conditions, was provided by the analytical laboratory of the Department of Ecology and Natural Resources of the Odessa Regional State Administration of Odessa, Ukraine.

\section{Research results}

6.1. Atmospheric conditions under which a condensate of atmospheric moisture is obtained. Information on atmospheric conditions on the day of sampling condensate of atmospheric moisture, obtained experimentally, is given in Table 5 .
Table 4

Methods and equipment for the study of air pollution*

\begin{tabular}{|c|c|c|c|c|c|}
\hline \multirow{2}{*}{$\begin{array}{l}\text { Pollutant of } \\
\text { atmospheric } \\
\text { air }\end{array}$} & \multirow{2}{*}{ Method of determination } & \multirow{2}{*}{$\begin{array}{c}\text { Range of } \\
\text { concentra- } \\
\text { tion mea- } \\
\text { surement, } \\
\mathrm{mg} / \mathrm{m}^{3}\end{array}$} & \multicolumn{2}{|c|}{$\begin{array}{l}\text { Limits of mea- } \\
\text { surement error }\end{array}$} & \multirow{2}{*}{ Equipment } \\
\hline & & & $\begin{array}{l}\text { Redu- } \\
\text { ced, \% }\end{array}$ & $\begin{array}{l}\text { Rela- } \\
\text { tive, \% }\end{array}$ & \\
\hline $\begin{array}{l}\text { 1. Carbon } \\
\text { oxide }\end{array}$ & $\begin{array}{l}\text { The method assumes oxidation } \\
\text { of carbon monoxide to dioxide, } \\
\text { absorption of the latter with a } \\
\text { weak alkali solution, followed by } \\
\text { a conductometric determination } \\
\text { of the amount of carbon dioxide }\end{array}$ & $3 \ldots 50$ & - & \pm 20 & $\begin{array}{c}\text { Gas analyzer } \\
\text { K-100 (Russia) }\end{array}$ \\
\hline 2. Ozone & $\begin{array}{l}\text { The concentration of ozone in } \\
\text { air is carried out by electric } \\
\text { discharge method }\end{array}$ & $0 \ldots . .0 .50$ & \pm 20 & \pm 25 & $\begin{array}{c}\text { Gas analyzer } \\
\text { P-310 A (Russia) }\end{array}$ \\
\hline 3. Ammonia & $\begin{array}{l}\text { The mass concentration of am- } \\
\text { monia in samples of atmospheric } \\
\text { air is determined by the pho- } \\
\text { tometric method with sodium } \\
\text { salicylate }\end{array}$ & $0.02 \ldots .5 .0$ & \pm 25 & \pm 22 & $\begin{array}{c}\text { Gas analyzer } \\
\text { P-310 A (Russia) }\end{array}$ \\
\hline 4. Dust & $\begin{array}{l}\text { The dust load is monitored with } \\
\text { a dust factor by measuring the } \\
\text { content of free silican dioxide }\end{array}$ & $0 . .30$ & \pm 20 & \pm 20 & $\begin{array}{c}\text { Dust Analyzer } \\
\text { DAСT (Russia), filters } \\
\text { AФА-BП-10 (Russia) }\end{array}$ \\
\hline $\begin{array}{l}\text { 5. Nitrogen } \\
\text { dioxide }\end{array}$ & $\begin{array}{l}\text { Mass concentrations of oxide } \\
\text { and nitrogen dioxide are deter- } \\
\text { mined by the reaction with the } \\
\text { Griss-llosvay reagent using the } \\
\text { photometry method }\end{array}$ & $0 \ldots .20 .0$ & \pm 23 & \pm 8 & $\begin{array}{l}\text { The device for } \\
\text { sampling air type } \\
\text { ПA-40M-1 (Russia), } \\
\text { photometer photovol- } \\
\text { taic KФK-3 (Russia) }\end{array}$ \\
\hline $\begin{array}{l}\text { 6. Hydrogen } \\
\text { sulfide }\end{array}$ & $\begin{array}{l}\text { The method consists in absorb- } \\
\text { ing hydrogen sulphide from the } \\
\text { test gas with an acidified solution } \\
\text { of zinc acetate and further spec- } \\
\text { trophotometric determination of } \\
\text { methylene blue, formed in an } \\
\text { acid medium by the interaction } \\
\text { of zinc sulfide with dimethyl-l- } \\
\text { phenylenediamine in the pre- } \\
\text { sence of ferric chloride (III) }\end{array}$ & $0 \ldots . .3$ & \pm 25 & - & $\begin{array}{c}\text { Gas analyzer } \\
\text { CB-320 (Bussia), } \\
\text { photometer photovol- } \\
\text { taic KФК-2 MП (Rus- } \\
\text { sia) gas drum counter } \\
\text { PГ-7000 (Russia), } \\
\text { barometer-aneroid } \\
\text { БАMM-1 (Russia) }\end{array}$ \\
\hline $\begin{array}{l}\text { 7. Sulfuraus } \\
\text { anhydride }\end{array}$ & $\begin{array}{l}\text { The method is based on fluo- } \\
\text { rescent light emission by } \mathrm{SO}_{2} \\
\text { molecules preliminarily excited } \\
\text { by ultraviolet radiation }\end{array}$ & $0 \ldots .0 .05$ & \pm 25 & \pm 2 & $\begin{array}{l}\text { Gas analyzer op } \\
\text { CB-320 (Russia) }\end{array}$ \\
\hline $\begin{array}{l}\text { 8. Saturated } \\
\text { hydrocar- } \\
\text { bons }\end{array}$ & $\begin{array}{l}\text { Mass concentrations of saturated } \\
\text { hydrocarbons } \complement_{12}-\complement_{19} \text { (in terms } \\
\text { of total organic carbon) are mea- } \\
\text { sured by chromatographic me- } \\
\text { thod, based on the use of the } \\
\text { properties of complex mixtures } \\
\text { on a chromatographic column }\end{array}$ & $0.2 \ldots 1000$ & - & \pm 20 & $\begin{array}{c}\text { Chromatograph with } \\
\text { automatic sampling } \\
\text { Kpистал-5000.1 } \\
\text { (Russia) }\end{array}$ \\
\hline
\end{tabular}

Note: ${ }^{*}$ - the data are taken from [28-32].
Table 5

Experimental data on atmospheric conditions in places of water condensate extraction

\begin{tabular}{|c|c|c|}
\hline \multirow{2}{*}{ Indicator } & \multicolumn{2}{|c|}{$\begin{array}{l}\text { Conditioner } \\
\text { No. } 1\end{array}$} \\
\hline & $\begin{array}{l}\text { Mid- } \\
\text { night }\end{array}$ & $\begin{array}{l}\text { Mid- } \\
\text { day }\end{array}$ \\
\hline Air temperature, ${ }^{\circ} \mathrm{C}$ & +17 & +24 \\
\hline Atmospheric pressure, mm Hg & 753 & 765 \\
\hline Relative humidity, \% & 82 & 75 \\
\hline Wind speed, m/s & 3 & 6 \\
\hline Condensate flow, $\mathrm{dm}^{3} / \mathrm{h}$ & 0.25 & 0.4 \\
\hline Condensate temperature, ${ }^{\circ} \mathrm{C}$ & +12 & +16 \\
\hline \multirow{2}{*}{ Indicator } & \multicolumn{2}{|c|}{$\begin{array}{l}\text { Conditioner } \\
\text { Na. } 2\end{array}$} \\
\hline & $\begin{array}{l}\text { Mid- } \\
\text { night }\end{array}$ & $\begin{array}{l}\text { Mid- } \\
\text { day }\end{array}$ \\
\hline Air temperature, ${ }^{\circ}[$ & +19 & +26 \\
\hline Atmospheric pressure, mm $\mathrm{Hg}$ & 750 & 770 \\
\hline Relative humidity, \% & 84 & 78 \\
\hline Wind speed, m/s & 5 & 7 \\
\hline Condensate flow, $\mathrm{dm}^{3} / \mathrm{h}$ & 0.35 & 0.5 \\
\hline Condensate temperature, ${ }^{\circ}[$ & +14 & +19 \\
\hline \multirow{2}{*}{ Indicator } & \multicolumn{2}{|c|}{$\begin{array}{l}\text { Conditioner } \\
\text { Na. } 3\end{array}$} \\
\hline & $\begin{array}{l}\text { Mid- } \\
\text { night }\end{array}$ & $\begin{array}{l}\text { Mid- } \\
\text { day }\end{array}$ \\
\hline Air temperature, ${ }^{\circ}[$ & +18 & +27 \\
\hline Atmospheric pressure, mm Hg & 760 & 777 \\
\hline Relative humidity, \% & 88 & 80 \\
\hline Wind speed, m/s & 5 & 7 \\
\hline Condensate flow, $\mathrm{dm}^{3} / \mathrm{h}$ & 0.45 & 0.59 \\
\hline Condensate temperature, ${ }^{\circ} \mathrm{C}$ & +12 & +16 \\
\hline
\end{tabular}


Analysis of the obtained results (Table 5) allows to note the following:

- increase in temperature and humidity of the environment, as well as increase in wind speed, causes an increase in the amount of water obtained from the air with the help of a domestic air-conditioner;

- the amount of atmospheric moisture condensed with the aid of Sensei FTB-25GR and Sensei FTI-25MR air conditioners (Table 1 ) at an ambient temperature of 17 to $24^{\circ} \mathrm{C}$, relative humidity ranging from 75 to $88 \%$, and wind speed ranging from 3 up to $7 \mathrm{~m}$ is an average of 7.5 to $12.5 \mathrm{dm}^{3} /$ day.

6.2. Contamination of atmospheric air in places of water production. The results of determining the contamination of atmospheric air by various impurities in experimental conditioners are given in Table 6 .

As can be seen from Table 6, high concentrations of carbon monoxide, hydrocarbons, and ammonia are observed in samples of air sampled from three experimental conditioners. In all air samples, the excess of the MPC value is based on the content of hydrocarbons, and the carbon monoxide content is close to the MPC value.

The high content of such pollutants in air samples can be explained by the fact that carbon dioxide and hydrocarbons are products of combustion of various fuels (coal, oil, natural gas, biomass), which uses transport and industrial enterprises [34]. In Table 2 it can be seen that there are a lot of transport highways and enterprises around the locations of experimental air conditioners. The reason for the high content of ammonia in the air can be the activity of the enterprise for the production and sale of ammonia, urea and fertilizers in the city of Yuzhny, Ukraine (Odessa Refinery), and the activities of rural farms.

Analysis of the experimental data given in Table 6. The following regularity are also revealed: the concentration of pollutants (carbon monoxide, ammonia, hydrogen sulfide, ozone) in all air samples is higher in the daytime, and the concentration of dust in the air is at night. This can be explained by the fact that it is during the day that traffic flows and the activities of enterprises are more intensive. During the night, on the contrary, more favorable conditions are created for the deposition of solid particles from the air and their accumulation in the surface layer of the atmosphere.
In terms of the content of nitrogen dioxide, sulfurous anhydride and saturated hydrocarbons in air samples, a similar pattern is not observed. Thus, for samples of air taken from air conditioners No. 1 and No. 2, the content of nitrogen dioxide, sulfurous anhydride and saturated hydrocarbons is higher in the daytime, and for air samples obtained at air conditioner No. 3 above at night (Table 6).

The increase in ozone concentration in the air during the day can be explained by the fact that in the lower atmosphere (up to $30 \mathrm{~km}$ from the surface of the Earth) ozone can additionally be formed as a result of photochemical reactions, in particular, in the interaction of nitrogen oxides and hydrocarbons [34]. As already noted above, in the daytime, the concentration of nitrogen oxides in the air increases. The concentration of hydrocarbons in the air also increases due to more intensive evaporation of water from the sea surface.

The increase in the concentration of hydrogen sulphide in the air during the day is explained by the more intensive industrial activity during this period. After all, it is a composite of gas emissions, in particular, chemical and oil refineries. In addition, do not forget about hydrogen sulphide, which is located in the anoxic layers of the Black Sea. The mixing of water in the sea can cause the rise of hydrogen sulfide to the surface of the sea and its entry into the atmosphere along with water splashes.

It is advisable to note that nitrogen dioxide is a product of combustion of fossil fuels containing nitrogen compounds and a product of photochemical oxidation of air nitrogen. It is a composite exhaust gas transport emissions, and its concentration is determined by the regime and organization of combustion processes. The greatest concentration of nitrogen dioxide is observed at the crossroads and car parks, where transport operates on interchangeable regimes. Also, nitrogen oxides fall into the air with the emissions of chemical industry enterprises, the production of mineral fertilizers, bacterial decomposition of silage. For sulfurous anhydride, it is the main representative of smoke emissions of boiler units [34]. Since exhaust and flue gases due to intensive traffic and the activity of enterprises are formed in the daytime more, in air samples the concentration of the constituents of these gases is higher precisely on the day.

The content of pollutants in the ambient air

\begin{tabular}{|c|c|c|c|c|c|c|c|c|c|}
\hline \multirow[b]{2}{*}{ Conditioner } & \multirow[b]{2}{*}{ Time to sample air } & \multicolumn{8}{|c|}{ The content of pollutant, $\mathrm{mg} / \mathrm{m}^{3}$} \\
\hline & & $\begin{array}{l}\text { Carbon } \\
\text { oxide, } \\
\mathrm{mg} / \mathrm{m}^{3}\end{array}$ & $\begin{array}{l}\text { Dzone, } \\
\mathrm{mg} / \mathrm{m}^{3}\end{array}$ & $\begin{array}{c}\text { Ammonia, } \\
\mathrm{mg} / \mathrm{m}^{3}\end{array}$ & $\begin{array}{l}\text { Dust, } \\
\mathrm{mg} / \mathrm{m}^{3}\end{array}$ & $\begin{array}{l}\text { Nitrogen } \\
\text { dioxide, } \\
\mathrm{mg} / \mathrm{m}^{3}\end{array}$ & $\begin{array}{l}\text { Hydragen } \\
\text { sulfide, } \\
\mathrm{mg} / \mathrm{m}^{3}\end{array}$ & $\begin{array}{l}\text { Anhydride } \\
\text { sulfur, } \\
\text { mg/m }\end{array}$ & $\begin{array}{l}\text { Saturated hydrocarbons } \\
\complement_{12}-\complement_{19} \text { (in terms of total } \\
\text { organic carbon), mg/m }\end{array}$ \\
\hline \multirow{2}{*}{ No. 1} & Midnight & 3.2 & 0.018 & 0.054 & 0.0852 & 0.015 & 0.0012 & 0.006 & 1.1 \\
\hline & Midday & 4.8 & 0.01 & 0.07 & 0.08 & 0.02 & 0.002 & 0.015 & 1.25 \\
\hline \multirow{2}{*}{ No. 2} & Midnight & 3.2 & 0.0018 & 0.054 & 0.0852 & 0.015 & 0.0012 & 0.006 & 1.1 \\
\hline & Midday & 4.99 & 0.015 & 0.06 & 0.023 & 0.02 & 0.002 & 0.015 & 1.25 \\
\hline \multirow{2}{*}{ No. 3} & Midnight & 4.6 & 0.0015 & 0.042 & 0.099 & 0.12 & 0.0012 & 0.045 & 1.2 \\
\hline & Midday & 4.99 & 0.015 & 0.06 & 0.044 & 0.033 & 0.0044 & 0.018 & 1.012 \\
\hline \multicolumn{2}{|c|}{ MPC (maximum single), mg/m $/ \mathrm{m}^{3 *}$} & 5 & 0.16 & 0.2 & 0.5 & 0.085 & 0.008 & 0.5 & 1 \\
\hline
\end{tabular}

Note: ${ }^{*}$ - the data are taken from [33]. 
For samples of air taken from the air conditioner No. 3, the reason for the increase in the content of $\mathrm{NO}_{2}, \mathrm{SO}_{2}$ and saturated hydrocarbons at the night could be an event in the seaport of large-capacity oil tankers. In addition, it could have been influenced by the clumps of cars on the parking lot of the Langeron beach at restaurants and entertainment establishments on weekends that were on the eve of the air sampling day.

It should be noted that a clear pattern of the influence of the height of placement of air conditioners and their remoteness from the coastal strip within the range of these values in the ranges in Table 2 was not found. Obviously, the decisive influence on the content of pollutants in the atmospheric air is detected by the distance from the experimental air-conditioners to the transport highways (automobile, sea and rail) and industrial enterprises. This is confirmed, in particular, by the chemical composition of the air samples taken from the air conditioner No. 3 (Langeron beach, Odessa, Ukraine). They have a high content of carbon monoxide, nitrogen dioxide, dust, hydrogen sulphide, sulfurous anhydride (Table 6).

6.3. Forecasting of microbiological contamination degree of water produced from air using a domestic air conditioner. Microorganisms are the most numerous group of living beings in nature. They are in the air, water, soil, plants, objects, products, on the surface and in the organisms of birds, animals and people. The properties of microorganisms are also very diverse. They easily adapt to power sources, in the majority - resistant to lack of moisture, temperature fluctuations, are able to multiply quickly.

In the literature $[34,35]$ it is noted that atmospheric air is an unfavorable environment for the propagation of microorganisms, since solar, ultraviolet and other radiation has a harmful effect on bacteria and viruses, for pigment formation. At the same time, sources of air pollution can be soil, ponds, people, animals, plants, various household wastes, and the like.

It is known that in the soil the vital activity of nitrifying, denitrifying and putrefactive bacteria, sulfur and iron bacteria, hydrogen-oxidizing (hydrogen), microorganisms, decomposing cellulose and pectin, actinomycetes, archaebacteria, mycoplasmas, mold fungi, yeast, opportunistic and pathogenic, zoopathogenic and phytopathogenic microorganisms [35]. The composition of the microbiota is heterogeneous and variable and varies depending on the type of soil, water, oxygen, weather and climate conditions and many other reasons.

Soil is the main pollutant of air by microorganisms. Microorganisms from the soil can enter the airspace of the room when it is being ventilated, be brought in with clothes and shoes of people, with vegetables and fruits, as well as pets. Especially dangerous are the bacteria of the Escherichia coli group (BECG) - the presence of Escherichia coli, Salmonella, Shigella and Proteus, as well as mold fungi and yeast, enterococci and pathogenic microorganisms.

Since all air conditioners in the experiment are located near the sea shore, the air can also be polluted by microorganisms that fall with water droplets are lifted by air masses from the sea surface. Sea air, in comparison with the air of settlements, is considered quite clean. At the same time, the authors of [35] indicate the possibility of the presence of pseudomonads, micrococci and enterococci in samples of sea air.
It should not forget about the human factor. After all, it is known that the air of closed, contaminated rooms, with poor ventilation, with a large population of people is more polluted by microorganisms than pure ventilated. In the premises, human microorganisms get from the surface of the skin, particularly dirty hands (staphylococci, micrococci, sarcin, actinomycetes, mold fungi, mycobacteria, yeast, streptococcus), from the mucous membranes of the respiratory tract (streptococci, staphylococci, actinomycetes, spirochetes and others).

Modern air conditioners are equipped with different air filters. In particular, the conditioners used in the experiment (Table 1) contain a mechanical filter and filters for air disinfection of various operating principles (plasma in conditioner 1 and antioxidant in air conditioners No. 2 and No. 3). According to manufacturers' information, such filters are effective against bacteria and viruses [16, 17], so it would be possible to assume that there will be no microorganisms in the water or their quantity will be insignificant. But there are a number of factors which influence makes this impossible. Firstly, it is the presence in the air conditioner of looseness in the housing, which allows free penetration of unfiltered air inside the equipment. Secondly, it is contact with the environment of the tube to drain the condensed moisture, and, as a consequence, the ingress of pollutants into it. Thirdly, the absence or non-observance of the sanitary treatment regimes of the internal working surfaces of the air conditioner and the conduits for draining the condensed moisture help to increase the number of microorganisms in the water.

Taking into account the above, it can be predicted that water samples are characterized by the qualitative and quantitative composition of a diverse microbiota. In addition, the increased content of carbon, nitrogen and sulfur compounds in the air (Table 6), as well as comfortable temperature and humidity (Table 5), constant access of oxygen to the air conditioner create favorable conditions for the life of microorganisms. To confirm these assumptions, experimental microbiological studies are performed.

6.4. The results of experimental studies of indicators of epidemic safety and other microbiological indicators of water from the air. The results of an experimental study of the microbiological indicators of the quality of water samples produced with the help of household conditioners are given in Tables 7, 8. In Tables 7, 8, the water sample number corresponds to the air conditioner number (according to Table 2).

Analysis of the research results of epidemiological safety indicators (Table 7) shows that water samples from air obtained with the help of all experimental conditioners are characterized by a significant excess of regulatory requirements [3]. In this case, the values of the quality indicators are worse than those for water samples obtained at noon. During this period of the day the air was more polluted and the temperature was not very high. A clear influence of other factors (design features of air conditioners, remoteness to the air conditioning from the sea coast, industrial enterprises, transport highways) on the indicators of epidemic safety of water in the experiment is not established.

Exceeding the standard for the total microbial number (Table 7) indicates the presence of a significant amount of mesophilic aerobic, facultative anaerobic microorganisms in the water, as well as the probability of opportunistic microorganisms. 
Indicators of epidemiological safety of water samples from air

\begin{tabular}{|c|c|c|c|c|c|c|c|}
\hline \multirow{3}{*}{ Water quality index, unit of measure } & \multicolumn{6}{|c|}{ Values of indicators } & \multirow{3}{*}{ Standard } \\
\hline & Midnight & Midday & Midnight & Midday & Midnight & Midday & \\
\hline & \multicolumn{2}{|c|}{ Sample No. 1} & \multicolumn{2}{|c|}{ Sample No. 2} & \multicolumn{2}{|c|}{ Sample No. 3} & \\
\hline $\begin{array}{l}\text { Total microbial number, } \mathrm{CFU} \text { in } \mathrm{cm}^{3} \text { : } \\
\text { - at } 22^{\circ} \mathrm{C}_{;} \\
\text {- at } 37^{\circ} \mathrm{C}\end{array}$ & $\begin{array}{l}>300 \\
>300\end{array}$ & $\begin{array}{l}>300 \\
>300\end{array}$ & $\begin{array}{l}>300 \\
>300\end{array}$ & $\begin{array}{l}>300 \\
>300\end{array}$ & $\begin{array}{l}>300 \\
>300\end{array}$ & $\begin{array}{l}>300 \\
>300\end{array}$ & $\begin{array}{l}\text { Not determined } \\
\leq 100\end{array}$ \\
\hline General coliforms, CFU per $100 \mathrm{~cm}^{3}$ & $>3 \cdot 10^{4}$ & $>3 \cdot 10^{4}$ & $>24 \cdot 10^{4}$ & $>30 \cdot 10^{4}$ & $>3 \cdot 10^{4}$ & $>3 \cdot 10^{4}$ & Absent \\
\hline E. coli, CFU per $100 \mathrm{~cm}^{3}$ & $>3 \cdot 10^{3}$ & $>3 \cdot 10^{3}$ & $>19 \cdot 10^{3}$ & $>20 \cdot 10^{3}$ & $>3 \cdot 10^{3}$ & $>3 \cdot 10^{3}$ & Absent \\
\hline Enteracacci, CFU рег 100 cm $^{3}$ & 40 & 45 & 42 & 49 & 4500 & 4000 & Absent \\
\hline Ps. aeruginosa, CFU рег $100 \mathrm{~cm}^{3}$ & 170 & 1000 & 1000 & 1000 & 1000 & 17000 & Absent \\
\hline
\end{tabular}

Table 8

Classification of bacteria in water samples from air

\begin{tabular}{|c|c|c|c|c|}
\hline Туре & Class & Order & The family and its share in the total number of bacteria & Species representative \\
\hline \multirow{3}{*}{ Eubacteria } & \multirow{3}{*}{ Asporulales } & Micracaccales & Micracaccacea - $13.9 \%$ & St. аuгеas \\
\hline & & \multirow{2}{*}{ Bacteriales } & Pseudomonadaceae - $36.1 \%$ & Ps. aeruginasa \\
\hline & & & Enterobacteriaceae - $41.7 \%$ & E. coli \\
\hline \multicolumn{5}{|c|}{ Dther bacteria - $8.3 \%$} \\
\hline
\end{tabular}

Confirmation of this is the conditionally pathogenic bacteria found in the water of the genus E. coli and Ps. aeruginosa. When bacteria were cultivated on special media and their differentiation, pathogenic bacteria of the genus St. aureus were found [1].

The microbiological studies made it possible to determine the structure of the microorganism community in water with their percentage. In particular, Table 8 shows the classification (according to [36]) of bacteria in water samples collected during operation of conditioner No. 1.

From Table 8 it can be seen that the most numerous in water samples are conditionally pathogenic bacteria of the families Enterobacteriaceae and Pseudomonadaceae. The characteristic features of representatives of these genera are that they are gram-negative rod-shaped bacteria and develop both under aerobic and anaerobic conditions. In particular, the bacteria of the family Pseudomonadaceae use oxygen as an electron acceptor under aerobic conditions, and in anaerobic - nitrates, which confirms their rapid development under conditions of water production from air [37].

Since the bacteria identified in the experiment (Table 8) are heterotrophic microorganisms, it can be assumed that autotrophs are present in the water samples [35]. Because for their development in the water, produced from the air with the help of air conditioners, there are good conditions. Air, cooled in air conditioners, is polluted by inorganic compounds of carbon, nitrogen and sulfur. When moisture condenses from the air, they enter the water and form a nutrient medium for the development of chemoautotrophs. The latter assimilate inorganic compounds: carbon for the synthesis of carbohydrates, ammonia or nitrate nitrogen for the synthesis of amino acids and the like. The main source of energy for such processes is chemical energy, which is obtained by chemoautotrophs as a result of oxidation-reduction reactions (oxidation of nitrogen nitrifying bacteria in ammonium compounds to nitrites and nitrates, oxidation of hydrogen sulfide to sulfuric acid sulfate bacteria). The presence of photoautotrophic microorganisms in water (they use solar energy as a source of energy) is unlikely, because when operating the air-conditioning unit of water accumulation and its transportation, light-tight containers and channels are inside.

Analyzing the data of Table 8 it can be noted that in samples of water from the air of pathogenic bacteria, including gram-positive bacteria of the genus St. aureus, is significantly less than the opportunistic bacteria $E$. coli and Ps. aeruginosa. This correlation between pathogenic and opportunistic bacteria can be explained as follows. Since the air conditioner works indoors periodically, conditions with nutrient deficiencies, low humidity, other $\mathrm{pH}$, and enzymatic processes are created on working surfaces in contact with water. In addition, the bacteria E. coli and Ps. aeruginosa, produce secondary metabolites that have toxic and inhibitory activity against competing bacteria [35, 37]. Pathogenic bacteria are more sensitive and can't stand competition in the struggle for survival. The temperature factor also influences. Optimum temperature for development of St. aureus is a temperature regime in the range from +30 to $+37{ }^{\circ} \mathrm{C}$. Under the experimental conditions, the condensate temperature ranges from +12 to $+16{ }^{\circ} \mathrm{C}$ at ambient temperatures from +17 to $+27{ }^{\circ} \mathrm{C}$ (Table 5).

It is important to note that the bacteria of the genus E. coli and Ps. aeruginosa are saprophytes. These bacteria decompose the substances of dead microorganisms under the action of hydrolytic enzymes. In addition to them, in the process of biological destruction of biomass, mold fungi and yeast are also involved. In experimental samples of water from air, obtained with the help of a domestic conditioner No. 1, the percentage of molds is determined. It is as follows: the fungi of the genus Penicillium are $19.4 \%$, the genus Cladosporium is $11.1 \%$, the genus Aspergillus is $8.4 \%$, and their associations are $19.4 \%$. In particular, it has been established that the fungi of the genus Cladosporium and Penicillium in the associations are found to be dominant. It should be noted that mold fungi of the genus Aspergillus are not dominant, but they 
are toxic, which provoke very dangerous for human life mycotoxins and, thus, mycotoxicoses.

For detection of all microorganisms in water produced from air using air conditioners, it would be necessary to perform still a significant number of experimental studies. This information is interesting, and in the framework of this paper this task is not raised. After all, from the analysis of the performed studies it is clear that it is dealed with a certain microbiocenosis. It contains autotrophic and heterotrophic, aerobic and anaerobic microorganisms. The qualitative composition of the microbiocenosis is formed under the influence of the environment and is regulated by the interrelations between microorganisms.

To develop a technology for the subsequent treatment of water produced from air, the main conclusion from the conducted microbiological studies is the conclusion about the mandatory disinfection of such water. The use of untreated water can cause infectious diseases, toxicoses and mycotoxicoses, which, as a rule, are accompanied by gastrointestinal disorders, violation of the work of individual organs and systems, and a decrease in immunity.

\section{SWOT analysis of research results}

Strengths. The studies carried out in the work show that atmospheric air and domestic air-conditioning can be an alternative source and means for obtaining water in regions with a deficit of fresh water. In addition, it is shown that the degree of air pollution and operating conditions of the air conditioner significantly affect the species and quantitative composition of the microflora of the condensate of atmospheric moisture. The strength of the work is that the necessity of obligatory disinfection of water, obtained with the help of domestic conditioners of split-systems, has been experimentally confirmed. The use of such process in water treatment technology will allow the use of atmospheric moisture condensate in both technical and drinking water supply.

Weaknesses. To select an effective method and rational technological regimes of disinfection of water from air, it is necessary to perform a number of studies. It is especially necessary to experimentally investigate the chemical composition of such water. This is important because individual components of water (for example, organic compounds or bromine), when interacting with disinfecting reagents of oxidative action can form toxic to humans compounds.

Opportunities. Information on sanitary and chemical indicators of water safety and quality will justify the choice of other processes for water treatment technology.

Threats. The condensate of atmospheric moisture is highly contaminated by microbiological indices. When developing technology to improve the quality of such water, understanding this alone is not enough. It is important to correctly determine the order of technological processes in the water treatment line. In this case, it is a question of the place of the water disinfection process in the technological line. Indeed, among the microflora present in the water from the air, are microorganisms capable of forming colonies on the surfaces of filtering materials of mechanical and sorption filters. As a result, the efficiency of water treatment processes is reduced, and the quality of water deteriorates. Therefore, in this case, the water treatment technology must begin in order to disinfect water. If the biological processes of water treat- ment are used in the technology, then in the previous disinfection of water there will be no need. In this case, the process of water disinfection will be the final stage of the technology.

\section{Conclusions}

1. The atmospheric conditions and the content of pollutants in the air in the places of obtaining water from it using household air-conditioners are determined. Condensates obtained during the day and night time of the day with change:

- air temperature - in the range from +17 to $+27{ }^{\circ} \mathrm{C}$;

- atmospheric pressure - in the range from 750 to

$777 \mathrm{~mm} \mathrm{Hg}$;

- relative humidity of air - in the range from 75 to $88 \%$;

- wind speed - in the range from 3 to $7 \mathrm{~m} / \mathrm{s}$.

The condensate flow rates in these atmospheric conditions ranged from 0.25 to $0.59 \mathrm{dm}^{3} / \mathrm{h}$. Concentrations of pollutants (in $\mathrm{mg} / \mathrm{m}^{3}$ ) in air samples varied within the following ranges during the day:

- carbon - from 3.2 to 4.99 ;

- ozone - from 0.0015 to 0.01 ;

- ammonia - from 0.042 to 0.07 ;

- dust - from 0.023 to 0.099 ;

- nitrogen dioxide - from 0.015 to 0.033 ;

- hydrogen sulfide - from 0.0012 to 0.002 ;

- sulfurous anhydride - from 0.006 to 0.045 ;

- saturated hydrocarbons - from 1.012 to 1.25 .

2. It is shown that the degree of pollution of atmospheric air with carbon monoxide, ozone, ammonia, dust, nitrogen dioxide, hydrogen sulfide, anhydride sulfurous and saturated hydrocarbons is most affected by the remoteness of air conditioners from industrial enterprises and transport highways. The influence of the height of placement of air conditioners above sea level and their remoteness of the coastal strip are insignificant under the conditions under which the experiment is conducted.

3. In the experimentally obtained samples of condensates of atmospheric moisture, the indicators of epidemic safety are determined, and the percentage relationships between the families of bacteria and the genera of mold fungi are established. It is found that the microbial number, determined at 22 and $37{ }^{\circ} \mathrm{C}$ in all samples of water from the air, is more than $300 \mathrm{CFU}$ in $\mathrm{cm}^{3}$. The significance of other indicators of the epidemic safety of water (in CFU per $100 \mathrm{~cm}^{3}$ ) varies in the following ranges: total coliforms - from $3 \cdot 10^{4}$ to $30 \cdot 10^{4} ;$ E. coli - from $3 \cdot 10^{3}$ to $20 \cdot 10^{3}$; enterococci - from 40 to 4500 ; Ps. aeruginosa from 170 to 17000 .

The structure of the community of bacterial families (in \%) in samples of water from air is as follows: Micrococcacea - 13.9; Pseudomonadaceae - 36.1; Enterobacteriaceae - 41.7; others -8.3 . The percentage ratio in the group of molds is as follows: genus Penicillium - 19.4; genus Cladosporium - 11.1; genus Aspergillus - 8.4, and their associations are $19.4 \%$. It is also found that the fungi of the genus Cladosporium and Penicillium in the associations appeared to be dominant.

4. It is established that water from air, produced with the help of household air-conditioners, has a very low quality by microbiological indices. None of the investigated indicators of the epidemic safety of water from the air 
does not correspond to the hygienic norms in force in Ukraine. Species composition of microorganisms is diverse. It contains autotrophic and heterotrophic, aerobic and anaerobic microorganisms. Microbiocenosis is formed under the influence of various factors (air pollution, operating mode and design features of the air conditioner).

5. It is impossible to use water obtained during the operation of wall conditioners for split-systems for drinking or technical needs. This is due to the presence in it of opportunistic and pathogenic bacteria, mold fungi and yeast. The use of such water can cause infectious diseases, toxicosis and mycotoxicosis, accompanied by gastrointestinal disorders, violation of the work of individual organs and systems, and a decrease in immunity. An obligatory process of improving the water as such must be its disinfection.

\section{References}

1. Kovalenko, O. O. Quality of the water received from air by means of conditioners [Text] / O. O. Kovalenko, K. Yu. Kormosh // Food Science and Technology. - 2016. - Vol. 10, No. 4. - P. 42-46. doi:10.15673/fst.v10i4.253

2. Ukrainskyi inzhener sproektuvav peresuvnu vitroustanovku, yaka mozhe zabezpechyty elektrykoiu i pytnoiu vodoiu voiniv u zoni ATO [Electronic resource] // EcoTown. - January 17, 2015. Available at: \www/URL: http://www.security-info.com.ua/news

3. DSanPiN 2.2.4.171.10. Hihiienichni vymohy do vody pytnoi, pryznachenoi dlia spozhyvannia liudynoiu [Electronic resource]. Available at: \www/URL: http://xn--80a2agee.xn--p1ai/dsanp$\mathrm{n}-2-2-4-171-10$

4. Owano, N. Lima billboard is tapped for drinking water [Electronic resource] / N. Owano // Phys.org. - February 25, 2013. Available at: \www/URL: https://phys.org/news/2013-02-limabillboard.html

5. Williams, A. Warka water promises to harness safe drinking water from the air [Electronic resource] / A. Williams // New Atlas. - January 23, 2015. - Available at: \www/URL: https:// newatlas.com/warka-water-from-air/35721

6. Owano, N. Self-filling water bottle takes cues from desert beetle [Electronic resource] / N. Owano // Phys.org. - November 25, 2012. - Available at: \www/URL: https://phys. org/news/2012-11-self-filling-bottle-cues-beetle.html

7. Osadchuk, E. A. Poisk energeticheski effektivnyh rezhimov raboty absorbtsionnyh vodoammiachnyh holodil'nyh mashin $\mathrm{v}$ sistemah polucheniia vody iz atmosfernogo vozduha [Text] / E. A. Osadchuk, A. S. Titlov, O. B. Vasyliv, S. Yu. Mazurenko // Naukovi pratsi ONAKhT. - 2014. - Vol. 1, No. 45. - P. 65-69.

8. Magrini, A. Production of Water from the Air: The Environmental Sustainability of Air-conditioning Systems through a More Intelligent Use of Resources. The Advantages of an Integrated System [Text] / A. Magrini, L. Cattani, M. Cartesegna, L. Magnani // Energy Procedia. - 2015. - Vol. 78. P. 1153-1158. doi:10.1016/j.egypro.2015.11.081

9. Hoffman, H. W. (Bill). Capturing the water you already have: Using alternate onsite sources [Text] / H. W. (Bill) Hoffman // Journal of American Water Works Association. - 2008. Vol. 100, No. 5. - P. 112-116.

10. Ananiev, V. A. Sistemy ventiliatsii i konditsionirovaniia. Teoriia i praktika [Text] / V. A. Ananiev, L. N. Balueva, A. D. Galperin, A. K. Gorodov, M. Yu. Eremin, S. M. Zviagintseva et al. Moscow: Evroklimat, 2001. - 416 p.

11. Condensate Water Introduction [Electronic resource] // Alliance for Water Efficiency. - 2012. - Available at: \www/ URL: http://www.allianceforwaterefficiency.org/Condensate_ Water Introduction.aspx

12. Wickman, F. How Gross Is the Water That Drips From Air Conditioners? [Electronic resource] / F. Wickman // Slate. July 15, 2013. - Available at: \www/URL: http://www.slate.com/ articles/news_and_politics/explainer/2011/08/how_gross_is_ the_water_that_drips_from_air_conditioners.html

13. Hermes, J. Air Conditioning Condensate Recovery [Electronic resource] / J. Hermes // Environmental Leader. - January 15, 2013. - Available at: \www/URL: https://www.environmentalleader.com/2013/01/air-conditioning-condensate-recovery/
14. Soltesz, D. L. How Can We Recycle A/C Water? [Electronic resource] / D. L. Soltesz // LIVESTRONG.COM. - June 13, 2017. - Available at: \www/URL: http://www.livestrong.com/ article/191991

15. Konditsionery Sensei [Electronic resource] // E-Katalog. 2017. - Available at: \www/URL: http://ek.ua/list/77/sensei/

16. Konditsioner Sensei FTI-25MR [Electronic resource] // E-Katalog. - 2017. - Available at: \www/URL: http://ek.ua/ SENSEI-FTI-25MR.htm

17. Treacy, M. Wind turbine makes 1,000 liters of clean water a day in the desert [Electronic resource] / M. Treacy // Treehugger. - April 16, 2012. - Available at: \www/URL: https://www.treehugger.com/wind-technology/wind-turbinemakes-clean-water-desert.html

18. MV 10.2.1-113-2005 Sanitarno-mikrobiolohichnyi kontrol yakosti pytnoi vody. Metodychni vkazivky [Electronic resource]. Available at: \www/URL: http://text.normativ.ua/doc9089.php

19. Pro zatverdzhennia metodychnykh rekomendatsii «Vyznachennia naibilsh virohidnoho chysla mikroorhanizmiv u vodi $\mathrm{z}$ vykorystanniam testiv diahnostychnykh Quanti-Disc ta SimPlate» [Electronic resource]: Order of the Ministry of Health of Ukraine No. 138 from March 14, 2008 // Informatsionnyi portal Ukrainy. - 2017. - Available at: \www/URL: http:// ua-info.biz/legal/basedw/ua-emtxvt.htm

20. Pro zatverdzhennia metodychnykh rekomendatsii «Zastosuvannia testovykh naboriv Colilert(R)-18 dlia sanitarno-bakteriolohichnoho kontroliu yakosti vody» [Electronic resource]: Order of the Ministry of Health of Ukraine No. 24 from January 24, 2007 // Verkhovna Rada Ukrainy. - 2017. - Available at: \www/ URL: http://zakon5.rada.gov.ua/rada/show/v0024282-07

21. Metodicheskie ukazaniia po sanitarno-mikrobiologicheskomu analizu vody poverhnostnyh vodoemov [Electronic resource]: Approved by the Ministry of Health of the USSR from January 19 1981 No. 2285-81 // Internet arhiv zakonodatel'stva SSSR. 2017. - Available at: \www/URL: http://www.libussr.ru/ doc_ussr/usr_10618.htm

22. Metodicheskie rekomendatsii. Vyiavlenie i identifikatsiia P. aeruginosa v obiektah okruzhaiushchei sredy (pishchevyh produktah, vode, stochnyh zhidkostiah) [Electronic resource]: Approved by the Ministry of Health of the USSR from May 24, 1984 Elektronnyi fond pravovoi i normativno-tehnicheskoi dokumentatsii. AO «Kodeks». - 2017. - Available at: \www/URL: http://docs.cntd.ru/document/1200049292

23. DSTU ISO10712-2003. Yakist vody. Test na pryhnichennia rostu Pseudomonas putida (test na pryhnichennia rozmnozhennia klityn Pseudomonas (ISO 10712:1995, IDT) [Electronic resource]: Order of the State Consumer Standard of Ukraine No. 102 from July 11, 2003. - Available at: \www/URL: http:// document.ua/jakist-vodi -test-na-prignichennja-rostu-pseudomonas-putida--std11438. $\overline{\text { html }}$

24. GOST R 52815-2007. Produkty pishchevye. Metody vyiavleniia i opredeleniia kolichestva koagulazopolozhitel'nyh stafilokokkov i Staphylococcus aureus [Electronic resource]: National Standard of the Russian Federation // Elektronnyi fond pravovoi i normativno-tehnicheskoi dokumentatsii. AO «Kodeks». Introduced: January 1, 2009. - 2017. - Available at: \www/ URL: http://docs.cntd.ru/document/1200069498

25. Honcharuk, V. V. Mikromitsety v pytnii vodi [Text] / V. V. Honcharuk, A. V. Rudenko, E. Z. Koval, O. S. Savluk, M. M. Saprykina // Visnyk NANU. - 2007. - No. 12. - P. 21-24.

26. Pro zatverdzhennia metodychnykh rekomendatsii «Sanitarnomikolohichni doslidzhennia pytnoi vody» [Electronic resource] Order of the Ministry of Health of Ukraine No. 226 from March 13, 2010 // IAS Konsultant. - 2017. - Available at: $\backslash$ www/URL: http://consultant.parus.ua/?doc=06B1M6F464

27. Posty ekologicheskie peredvizhnye PEP-1-1, mod. PEP-1-1 i PEP1-1M [Electronic resource] // Torgovyi Dom «Spets». - 2017. Available at: \www/URL: http://td-str.ru/file.aspx?id=3885

28. Klymenko, M. O. Monitorynh dovkillia [Text]: Handbook M. O. Klymenko, A. M. Pryshchepa, N. M. Vozniuk. - Kyiv: Vydavnychyi tsentr »Akademiia», 2006. - 360 p.

29. DSTU ISO 6879:2003 Yakist povitria. Kharakterystyky i nastanovy shchodo vymiriuvannia yakosti povitria [Electronic resource]: Order of the State Consumer Standard of Ukraine No. 189 from October 13, 2003. - Available at: \www/URL: http://document.ua/jakist-povitrja -harakteristiki-i-nastanovishodo-vimiryuvan-std10169.html 
30. DSTU ISO 4219:2004 Yakist povitria. Vyznachennia hazopodibnykh sirchystykh spoluk v navkolyshnomu povitri. Obladnannia dlia vidbyrannia prob [Electronic resource]: Order of the State Consumer Standard of Ukraine No. 219 from October 5, 2004. Available at: \www/URL: http://document.ua/jakist-povitrja_-viznachennja-gazopodibnih-sirchistih-spoluk-std9627.html

31. DSTU 2608-94 Analizatory haziv dlia kontroliu atmosfery. Zahalni tekhnichni vymohy i metody vyprobuvan [Electronic resource]: Order of the State Standard No. 161 from June 27, 1994. - Available at: \www/URL: http://document.ua/analizatori-gaziv-dlja-kontrolyu-atmosferi_zagalni-tehnichn-std707.html

32. GOST 17.0.0.02-79 Ohrana prirody. Metrologicheskoe obespechenie kontrolia zagriaznennosti atmosfery, poverhnostnyh vod i pochvy [Electronic resource]: Resolution of the USSR State Committee on Standards No. 3456 from September 11, 1979 // Elektronnyi fond pravovoi i normativno-tehnicheskoi dokumentatsii. AO «Kodeks». - 2017. - Available at: \www/ URL: http://docs.cntd.ru/document/1200003690

33. Derzhavni sanitarni pravyla okhorony atmosfernoho povitria naselenykh mists (vid zabrudnennia khimichnymy ta biolohichnymy rechovynamy) [Electronic resource]: Order of the Ministry of Health of Ukraine No. 201 from July 9, 1997 // Zakony Ukrainy. Informatsionno-pravovoi portal. - 2017. - Available at: www/URL: http://www.uazakon.com/big/text1359/pg2.htm

34. Plachkova, S. H. Section 2. Vplyv teploenerhetyky na navkolyshnie seredovyshche [Electronic resource]. Book 5. Elektroenerhetyka ta okhorona navkolyshnoho seredovyshcha. Funktsionuvannia enerhetyky v suchasnomu sviti / S. H. Plachkova, I. V. Plachkov, N. I. Dunaievska, V. S. Podhurenko et al. Enerhetyka: istoriia, suchasnist i maibutnie. - 2017. - Available at: \www/URL: http://www.energetika.in.ua/ua/books/ book-5/part-3/section-2

35. Chub, I. N. Konspekt lektsii po distsipline «Mikrobiologiia» [Text] / I. N. Chub, O. V. Bulgakova. - Kharkiv: KhNUGH, 2014. - 117 p.

36. Tehnicheskii spravochnik po obrabotke vody [Text]. - St. Petersburg: Novyi zhurnal, 2007. - Vol. 1. - 878 p.

37. Dege, N. Technology of Bottled Water [Text] / ed. by N. Dege. Wiley-Blackwell, 2011. - 448 p. doi:10.1002/9781444393330

\section{ВЛИЯНИЕ УСЛОВИЙ ПОЛУЧЕНИЯ ВОДЫ ИЗ ВОЗДУХА НА МИКРОБИОЦЕНОЗ КОНДЕНСАТА}

Представлены результаты теоретических и экспериментальных исследований влияния различных факторов на микробиоценоз воды из воздуха. Установлены закономерности между загрязненностью атмосферного воздуха различными примесями также особенностями эксплуатации настенных кондиционеров сплит-систем и рядом показателей микробиологического загрязнения воды. Показано, что вода, полученная из воздуха с помощью бытовых кондиционеров, характеризуется значительным микробиологическим загрязнением и без специальной очистки использовать ее для питьевых нужд опасно.

ключевые слова: атмосферный воздух, бытовой кондиционер, качество воды, микробиоценоз воды из воздуха.

Kovalenko Olena, Doctor of Technical Sciences, Senior Researcher, Department of Drinking Water Technology, Odessa National Academy of Food Technologies, Ukraine, e-mail: e kov@ukr.net, ORCID: https://orcid.org/0000-0002-8009-1103

Kormosh Katerina, Postgraduate Student, Department of Drinking Water Technology, Odessa National Academy of Food Technologies, Ukraine, e-mail: tommi2274@gmail.com, ORCID: https://orcid.org/ 0000-0001-6778-6229

Velichko Tetiana, PhD, Associate Professor, Department of Biochemistry, Microbiology and Nutrition Physiology, Odessa National Academy of Food Technologies, Ukraine, e-mail: biochem_onaft@ukr.net, ORCID: https://orcid.org/0000-0003-3971-5014

Vasyliv Oleg, PhD, Associate Professor, Department of Heat and Power Engineering and Pipeline Transport of Energy Resources, Odessa National Academy of Food Technologies, Ukraine, e-mail: oleg_vas@ukr.net, ORCID: https://orcid.org/0000-0002-0597-8863

Yemonakova Oksana, PhD, Associate Professor, Department of Bioengineering and Water, Odessa National Academy of Food Technologies, Ukraine, e-mail: emonakova2017@gmail.com, ORCID: https:// orcid.org/0000-0002-7001-8420

\section{Mazaeva V., Demidov I., Golodnyak V., Onopriyenko T.}

\section{CALCULATION OF PHYSICAL PROPERTIES OF FATS ON THEIR TRIACYLGYCLEROLE COMPOSITION}

Проведено дослідження по отриманню жирових сумішей з заданими властивостями. Визначено залежність між фізико-хімічними показниками і концентрацією компонентів (триацилгліщеролів) суміші. Також визначено тріацілглічерольний (ТАГ) склад переетеріфіщірованих жирів $і$ отриманих в ході експерименту жирових сумішей. Доведено, що існує функціональна залежність між ТАГ складом і фізико-хімічними показниками.

Ключові слова: тріацілглічерольний склад, температура плавлення, температура застигання, рослинне масло.

\section{Introduction}

The main component of fats (usually more than $95 \%$ ) is triacylglycerols. Triacylglycerol, and, consequently, fatty acid composition of fats is of great importance for the properties of food products containing fats $[1,2]$.

To obtain fatty products with specified physical-chemical and organoleptic properties, it is necessary to take into account the ratio of solid and liquid fats in the formulations of fatty foods. Physicochemical properties of fats affect the structure, stability, organoleptic characteristics and presentation of finished fat-containing products.

The composition of fatty foods for various food industries depends on many factors. The composition may be different, depending on the field of application, the process, the used equipment and many other features, and also depending on 